Article

\title{
Agro-Pellets from Oil Palm Residues/Pine Sawdust Mixtures: Relationships of Their Physical, Mechanical and Energetic Properties, with the Raw Material Chemical Structure
}

\author{
Artemio Carrillo-Parra ${ }^{1}{ }^{(}$, Juan Carlos Contreras-Trejo ${ }^{2}$, Marín Pompa-García ${ }^{2}{ }^{(}$, \\ Miguel Ángel Pulgarín-Gámiz ${ }^{2}$, José Guadalupe Rutiaga-Quiñones ${ }^{3}$, \\ Gerardo Pámanes-Carrasco ${ }^{1}$ and Maginot Ngangyo-Heya ${ }^{4, *}$ (D) \\ 1 Institute of Silviculture and Wood Industry (ISIMA), Juarez University of the State of Durango (UJED), \\ Boulevard del Guadiana 501, Ciudad Universitaria, Torre de Investigación, Durango 34120, Mexico; \\ acarrilloparra@ujed.mx (A.C.-P.); gapamanes@conacyt.mx (G.P.-C.) \\ 2 Forestry Faculty (FF), Juarez University of the State of Durango (UJED), Río Papaloapan and Blvd. Durango \\ S/N Col. Valle del Sur, Durango CP 34120, Mexico; jcarlosct1994@hotmail.com (J.C.C.-T.); \\ mpgarcia@ujed.mx (M.P.-G.); mpulgarin@ujed.mx (M.Á.P.-G.) \\ 3 Wood Technology Engineering Faculty (FITECMA), State University of Michoacán (UMSNH), Av. Fco J \\ Mugias s/n, CU, Col. Felicitas del Rio, Morelia CP 58040, Michoacán, Mexico; rutiaga@umich.mx \\ 4 Faculty of Agronomy (FA), Autonomous University of Nuevo León (UANL), Francisco Villa s/n, Col. \\ Ex-Hacienda "El Canadá", Escobedo 66050, Nuevo León, Mexico \\ * Correspondence: nheyamaginot@yahoo.fr; Tel.: +52-812-034-0601
}

Received: 28 August 2020; Accepted: 7 September 2020; Published: 13 September 2020

\begin{abstract}
The need for biomass as an alternative source for energy purposes points toward oil palm fruit residues (Elaeis guineensis Jacq.) as an attractive solution. Oil palm industry residue, such as oil palm empty fruit bunch (EFB) composites and mesocarp fiber (PMF), have a high gross calorific value and could help countries meet their energy demands. However, information concerning physical, mechanical, and energy characteristics of agro-pellets made from mixtures of oil palm residue with pine sawdust, is not available. In this research, oil palm residues were mixed at ratios of 100:0, 80:20, 60:40, 40:60, 20:80, and 0:100 with pine sawdust, and were chemically analyzed. Agro-pellets from mixtures were tested on their physical and mechanical properties, and the relationship of these properties with the chemical composition of oil palm residue mixtures was determined. Normality distribution tests of the variables were performed using the Kolmogorov-Smirnov test. Normal variables were analyzed through one-way ANOVA tests. When differences were found, they were validated using the Tukey's honestly significant difference (HSD) test and were considered statistically significant at $p \leq 0.05$. Data not normally distributed were analyzed by the Kruskal-Wallis test. Bulk density, particle density, and gross calorific value of agro-pellets (from mixing 80:20 oil palm residues with pine sawdust) were statistically higher $(p<0.05)$ to agro-pellets of $100 \%$ oil palm residues. Adding pine sawdust to oil palm residues increases some mechanical agro-pellet properties. Addition of pine sawdust to oil palm residues acts to increase some mechanical properties of agro-pellets.
\end{abstract}

Keywords: agro-pellets; bioenergy; biomass sources; oil palm fruit residues; pine sawdust

\section{Introduction}

Biomass is versatile, having zero net $\mathrm{CO}_{2}$ and less $\mathrm{SO}_{2}$ emissions than fossil fuels. It is one of the most promising energy alternatives to face climate change and can lessen dependence on fossil fuels $[1,2]$. However, being a heterogeneous material, solid biomass for energy purposes has some 
inconvenience, such as high moisture content, high hygroscopicity, low density, as well as difficulty to handle it and storage [3,4].

To solve these biomass problems, densification into pellets is one of the most available alternatives [5]. This process extrudes the raw material through holes drilled as cylindrical channel dies in a ring-shaped steel by press produced by rolls [6]. Friction forces among rolls, biomass, and the ring increase the temperature that reduces the moisture content, increasing the bulk density and energy density.

Essentially, pellets production is mainly based on sawdust from several sources, such as sawmills, carpentry, and other waste material $[7,8]$. If the pellet industry is still growing, it will reduce the raw materials availability $[9,10]$. Therefore, there is a growing interest in finding new materials that might be suitable for pelletization. Other biomass, as residues from agricultural production, might be among these new raw materials [11]. However, as a source of solid biomass for energy purposes, they have some disadvantages, such as low-density value $\left(40-400 \mathrm{~kg} \mathrm{~m}^{-3}\right)$, high moisture content $(>50 \%)$, non-uniform shapes, and size $(<0.2 \mathrm{~mm}$ up to $30 \mathrm{~mm})$ that limit their use [12,13].

Moreover, densification of agricultural waste could be an option, although some herbaceous biomass pellets (named, in this case, as "agro-pellets") could not fit the high quality of European standards, due to their low bulk density, high ash, potassium, and chlorine content [14]. Low bulk density increases storage and transport cost of pellets. Since feeding of boilers generally is volume-dependent, variations in bulk density should be avoided.

The calorific and compaction values of pellets have increased by mixing pine sawdust with lignosulfonates, residual potato flour, and potato peel residues [15]. Other mixtures of lignocellulose waste with high carbon sources increased the quality of biofuels pellets, on charcoal: sawdust 50:50, increasing the bulk density to $933 \mathrm{Kg} \mathrm{m}^{-3}$ and calorific values up to $24.2 \mathrm{MJ} \mathrm{kg}^{-1}$ [16].

Oil palm is an important source of oil worldwide, and its cultivation in Mexico increased to 97.8\% of planted area in the period between 1989 and 2013 [17]. During oil production from palm oil, companies mainly use fruit, but the industrial use of residues has not been yet reported. The basic characteristics of biofuels from oil palm residues have shown moderate higher heating values of 17.25 MJ kg-1, but low bulk density values and high ash content [18-20]. The aim of this research is to determine bulk density, compression ratio, and impact resistance of agro-pellets made from oil palm residue (Elaeis guineensis Jacq.) by adding pine sawdust at different mixtures ratios.

\section{Materials and Methods}

\subsection{Biomass Sources and Sampling}

The agro-industrial waste of palm empty fruit bunches (EFB) and mesocarp fiber (PMF) of Elaeis guineensis (oil palm residues) was obtained from Tacotalpa, Tabasco, Mexico, and the Pinus sp. sawdust (pine sawdust) was obtained from a sawmill from Durango, Durango, Mexico. The biomasses were conditioned up to moisture content of $15 \%$. Residues of both materials were chipped to reduce sizes, milled, and sieved up to $3 \mathrm{~mm}$ (to uniformize particle size). Oil palm residues were mixed at the ratios of 100:0, 80:20, 60:40, 40:60, 20:80, and 0:100 with pine sawdust.

\subsection{Agro-Pellets Production}

Agro-pellets from each of the mixtures were produced in a flat disc industrial pellet mill, brand ZSLP-R300, $8 \mathrm{~mm}$ length and $6 \mathrm{~mm}$ diameter channels, at $400 \mathrm{~kg} \mathrm{~h}^{-1}$, and maintained in plastic bags at laboratory conditions, $25^{\circ} \mathrm{C}$ and $65 \%$ of moisture content; further physical and chemical analysis were subsequently undertaken.

\subsection{Biomass Mixtures and Agro-Pellets Characterization}

Cellulose, hemi-cellulose, lignin, and extract contents of all biomass mixtures were determined through two repetitions of analysis based on the Van Soest gravimetric method [21]. Moisture content, 
volatile matter, and ash content of mixtures and agro-pellets were determined according to the international standards (The Spanish norm "UNE": Una Norma Española, and European Norm "EN"), UNE-EN 14774-3 [22], UNE-EN 15,148 [23], and UNE-EN 14,775 [24], respectively. Fixed carbon was determined by mass difference using Equation (1), and gross calorific value was determined in a calorimetric bomb according to UNE-EN-14918 [25]. Agro-pellet bulk density and particle density were determined according to the International Standardization Organization, UNE-EN ISO 17,828 [26], the compression ratio (CR) and impact resistance index (IRI) were determined according to Equations (2) and (3), respectively.

$$
F C=100-V V-A s h
$$

$F C$ is the fixed carbon (\%) and $\mathrm{Mv}(\%)$ is volatile material (\%).

$$
C R=\frac{P_{\text {pellet }}}{P_{\text {biomass }}}
$$

$C R$ is the compression ratio, $P_{\text {pellet }}\left(\mathrm{kg} \mathrm{m}^{-3}\right)$ is the density of pellet, and $P_{\text {biomass }}\left(\mathrm{kg} \mathrm{m}^{-3}\right)$ is the density of biomass mix.

$$
I R I=\left(\frac{100 N}{n}\right)
$$

$I R I$ is the impact resistance index, $N$ is the number of drops (2), and $n$ is the total number of pieces after $N$ drops [27].

\subsection{Statistical Analysis}

Since only two repetitions of chemical composition of each biomass mixture was obtained, just the mean and standard deviations were calculated. The percent data of immediate analysis was transformed by the arcsine square root function. Transformed data and calorific value of biomass mixtures, as well as energy, physical, and mechanical properties of pellets were examined to determine normality distribution by the Shapiro test [28]. Comparisons of chemical composition and bulk density among palm oil residues:pine sawdust mixes and bulk density, compression ratio, impact resistance index, and gross calorific values of agro-pellets were calculated through a one-way ANOVA. Where the F-test was significant $(p \leq 0.05)$, the differences were validated using the Tukey's honestly significant difference (HSD) test, and were considered statistically significant at $p \leq 0.05$ [29]. Variables with no normal distribution were statistically analyzed by the Kruskal-Wallis test; the relationship among pellet bulk density, impact resistance index, and gross calorific values with mixtures of oil palm residues:pine sawdust were calculated with the Pearson correlation coefficient $(r)$.

\section{Results}

\subsection{Chemical Characteristics, Proximate Analysis, and Bulk Density of Biomass Mixtures}

Cellulose, hemicellulose, lignin, and extract content on mixtures of oil palm residues:pine sawdust ranged from 44.16 to $56.64 \%, 14.14$ to $18.81 \%, 13.9$ to $25.02 \%$, and 4.20 to $22.17 \%$, respectively (Table 1 ). The highest value of cellulose and lignin was in the mixture 0:100; for hemicellulose, it was in the mixture 100:0; while with extract content, it was in the mixture 80:20.

ANOVA test values of volatile material and fixed carbon concentration on biomass mixtures showed significant statistical differences $(p<0.01$ ); values ranged from 83.95 to $91.86 \%$ and 7.83 to $15.54 \%$, respectively. Oil palm residue (100:0) showed the highest volatile material content (83.95\%) as well as the highest fixed carbon content (15.54\%). Kruskal-Wallis test of moisture content presented significant statistical differences $(p<0.01)$; values ranged from 7.58 to $10.14 \%$. Ash did not show statistical differences $(p>0.05)$, values ranged from 0.31 to $0.58 \%$. However, a non-linear behavior of these variables was recorded, with the highest values of 91.86 in the 80:20 mixture for volatile materials, 0.51 in the 100:0 mixture for the ash content, 10.14 (0:100) for the moisture content, and 15.54 (100:0) for fixed carbon. 
Table 1. Chemical characteristics, proximate analysis, and bulk density of oil palm residues:pine sawdust biomass mixtures.

\begin{tabular}{|c|c|c|c|c|c|c|}
\hline \multirow{2}{*}{$\begin{array}{l}\text { Biomass Mixtures } \\
\text { Characteristics }\end{array}$} & \multicolumn{6}{|c|}{ Oil Palm Residues:Pine Sawdust Mixtures } \\
\hline & 100:0 & $80: 20$ & $60: 40$ & 40:60 & $20: 80$ & $0: 100$ \\
\hline \multicolumn{7}{|c|}{ Structural compounds and extracts } \\
\hline Cellulose (\%) & $46.28(1.13)$ & $44.16(1.18)$ & $45.82(0.49)$ & $47.85(0.14)$ & $50.64(0.44)$ & $56.64(0.06)$ \\
\hline Hemicellulose (\%) & $18.81(0.49)$ & $18.58(0.16)$ & $17.33(0.63)$ & $15.92(0.29)$ & $14.56(0.12)$ & $14.14(0.20)$ \\
\hline Lignin $(\%)$ & $13.90(0.80)$ & $15.09(0.90)$ & $18.73(0.25)$ & $20.97(0.32)$ & $23.68(0.25)$ & $25.02(0.27)$ \\
\hline Extracts $(\%)$ & $21.01(0.65)$ & $22.17(0.45)$ & $18.12(0.63)$ & $15.26(0.44)$ & $11.12(0.50)$ & $4.20(0.43)$ \\
\hline \multicolumn{7}{|c|}{ Proximate analysis } \\
\hline Moisture content (\%) & $7.58(0.03) *$ & $9.84(0.047)$ & $9.28(0.11)$ & $8.88(0.18)$ & $7.66(0.32)$ & $10.14(0.09)$ \\
\hline Volatile material (\%) & $83.95(1.98)$ & $88.75(1.70)$ & $87.01(1.26)$ & $88.91(1.99)$ & $91.86(1.27)$ & $88.83(1.64)$ \\
\hline Ash $(\%)$ & $0.51(0.57)$ & $0.38(0.05)$ & $0.36(0.33)$ & $0.35(0.03)$ & $0.31(0.03)$ & $0.36(0.05)$ \\
\hline Fixed carbon (\%) & $15.54(1.92)$ & $10.86(1.72)$ & $12.63(1.29)$ & $10.73(1.97)$ & $7.83(1.30)$ & $10.81(1.66)$ \\
\hline \multicolumn{7}{|c|}{ Physical properties } \\
\hline Bulk density $\left(\mathrm{g} / \mathrm{cm}^{3}\right)$ & $0.12(0.01)$ & $0.15(0.01)$ & $0.17(0.01)$ & $0.20(0.01)$ & $0.21(0.01)$ & $0.20(0.01)$ \\
\hline
\end{tabular}

Regarding physical properties, bulk density showed statistical differences $(p<0.05)$ among biomass mixtures, and values ranged from 0.12 to $0.21 \mathrm{~kg} \mathrm{~m}^{-3}$ (Table 1). The higher bulk density values obtained on mixtures were on pine sawdust; proportion increased, since $40: 60\left(0.20 \mathrm{~g} / \mathrm{cm}^{3}\right)$, $20: 80\left(0.21 \mathrm{~g} / \mathrm{cm}^{3}\right)$, and $0: 100\left(0.20 \mathrm{~g} / \mathrm{cm}^{3}\right)$.

\subsection{Proximate Analysis, Physical, Mechanical, and Energy Characteristics of Agro-Pellets}

Volatile material and fixed carbon of agro-pellets showed statistical differences among mixtures $(p$ $<0.05$ ); values ranged from 83.95 to $91.86 \%$ and 7.83 to $15.54 \%$, respectively (Table 1). Moisture content and ash content did not show statistical differences $(p>0.05)$; they varied in the ranges $5.58-6.77 \%$ and $0.44-0.58 \%$, respectively. The bulk density, particle density, compression ratio, impact resistance index, and gross calorific values differed significantly $(p<0.05)$ among mixtures, presenting the ranges $550-680 \mathrm{Kg} \mathrm{m}^{-3}, 1090-1340 \mathrm{Kg} \mathrm{m}^{-3}, 3.28-4.74,105.5-157.5$, and 18.84-22.31 (MJ/Kg), respectively (Table 2). Gross calorific values showed statistical differences among mixtures and the values ranged from 18.84 to $22.31 \mathrm{MJ} \mathrm{Kg}^{-1}$ (Table 2).

Table 2. Proximate analysis, physical and mechanical characteristics of agro-pellets produced at different oil palm residues: pine sawdust mixtures.

\begin{tabular}{|c|c|c|c|c|c|c|}
\hline \multirow{2}{*}{ Pellets Characteristics } & \multicolumn{6}{|c|}{ Oil Palm Residues:Pine Sawdust Mixtures } \\
\hline & $100: 0$ & $80: 20$ & $60: 40$ & 40:00 & $20: 80$ & $0: 100$ \\
\hline \multicolumn{7}{|c|}{ Proximate analysis } \\
\hline Moisture content (\%) & $6.45(0.26)$ & $5.83(0.17)$ & $6.77(0.07)$ & $6.76(0.89)$ & $5.84(9.19)$ & $5.58(0.42)$ \\
\hline Material volatile (\%) & $79.40(1.90)$ & $80.04(1.47)$ & $80.41(1.02)$ & $87.32(1.92)$ & $85.68(1.63)$ & $89.31(3.68)$ \\
\hline Ash $(\%)$ & $0.54(0.07)$ & $0.54(0.05)$ & $0.58(0.04)$ & $0.44(0.11)$ & $0.53(0.07)$ & $0.44(0.08)$ \\
\hline Fixed carbon $(\%)$ & $20.05(1.83)$ & $19.42(1.42)$ & $19.01(0.98)$ & $12.23(1.81)$ & $13.79(1.57)$ & $10.25(3.60)$ \\
\hline \multicolumn{7}{|c|}{ Physical and mechanical properties } \\
\hline Bulk density $\left(\mathrm{Kg} \mathrm{m}^{3}\right)$ & $540(170)$ & $610(10)$ & $640(10)$ & $660(10)$ & $680(10)$ & $670(10)$ \\
\hline Particle density $\left(\mathrm{Kg} \mathrm{m}^{3}\right)$ & $1180(230)$ & $1240(220)$ & $1190(270)$ & $1250(370)$ & $1090(240)$ & $1340(520)$ \\
\hline Compression ratio & 4.74 & 4.13 & $3.74 \mathrm{~b}$ & 3.29 & 3.28 & 3.29 \\
\hline Impact resistance index & $158(65.44)$ & $155(78.89)$ & $144(72.75)$ & $114(28.65)$ & $126(50.31)$ & $108(27.02)$ \\
\hline \multicolumn{7}{|c|}{ Energy properties } \\
\hline $\begin{array}{c}\text { Gross calorific value } \\
(\mathrm{MJ} / \mathrm{Kg})\end{array}$ & $21.89(0.16)$ & $22.31(0.02)$ & $21.19(0.47)$ & $20.75(0.06)$ & $19.70(0.13)$ & $18.84(0.48)$ \\
\hline
\end{tabular}

Values in parentheses represent the standard deviation. 
3.3. Relationship of Agro-Pellet Properties with Chemical Characteristics of Oil Palm Residues:Pine Sawdust Mixtures

High degree of correlation coefficients $(r)$ were obtained between bulk density of pellets with the concentration of hemicellulose $(\mathrm{R}=0.85, p<0.0001)$, lignin $(\mathrm{R}=0.90, p<0.0001)$, cellulose $(\mathrm{R}=0.60$, $p<0.01)$, and extracts $(\mathrm{R}=0.75, p<0.001)$ (Figure 1$)$.

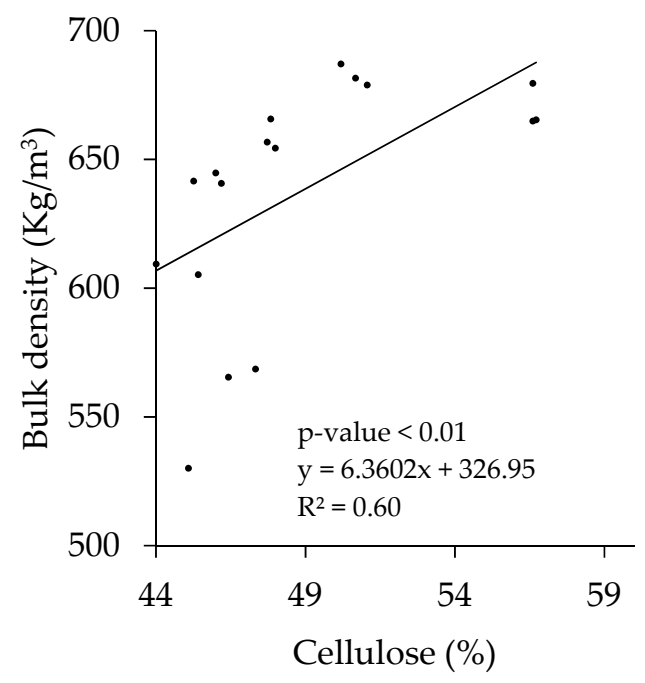

(a)

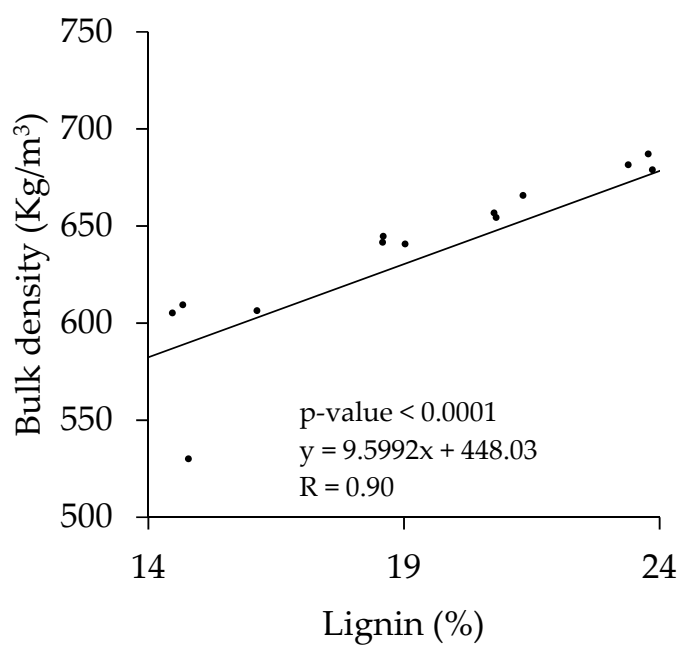

(c)

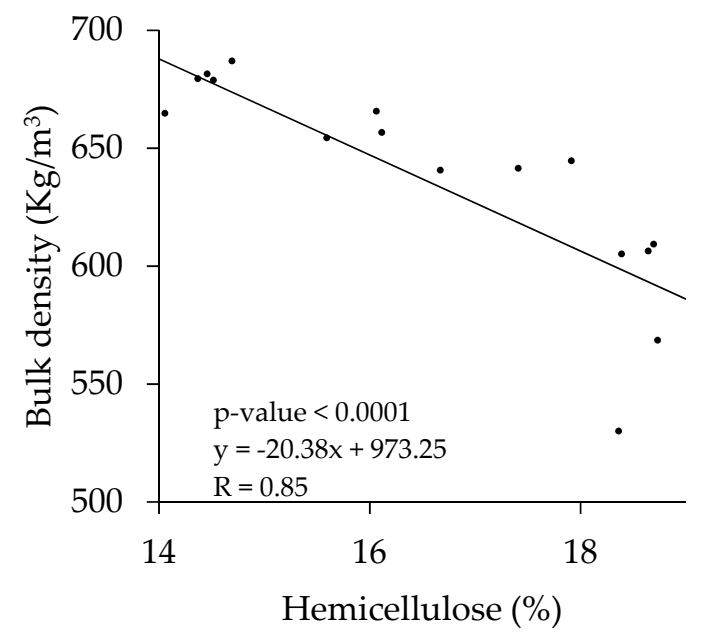

(b)

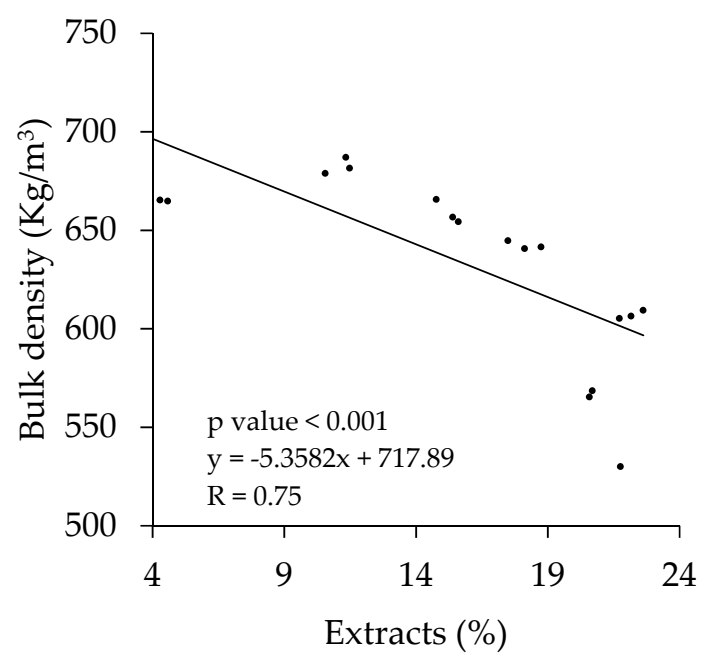

(d)

Figure 1. Relationship of agro-pellet bulk density with chemical components. (a) Cellulose; (b) hemicellulose; (c) lignin; (d) extract percentage of oil palm residues:pine sawdust mixtures.

Bulk density of agro-pellets also showed a high degree of correlation coefficients $(r)$ with oil palm residues:pine sawdust mixtures $(\mathrm{R}=0.91, p<0.001)$ and bulk density of oil palm residues:pine sawdust mixtures $(\mathrm{R}=0.96, p<0.01)$ (Figure 2$)$. 


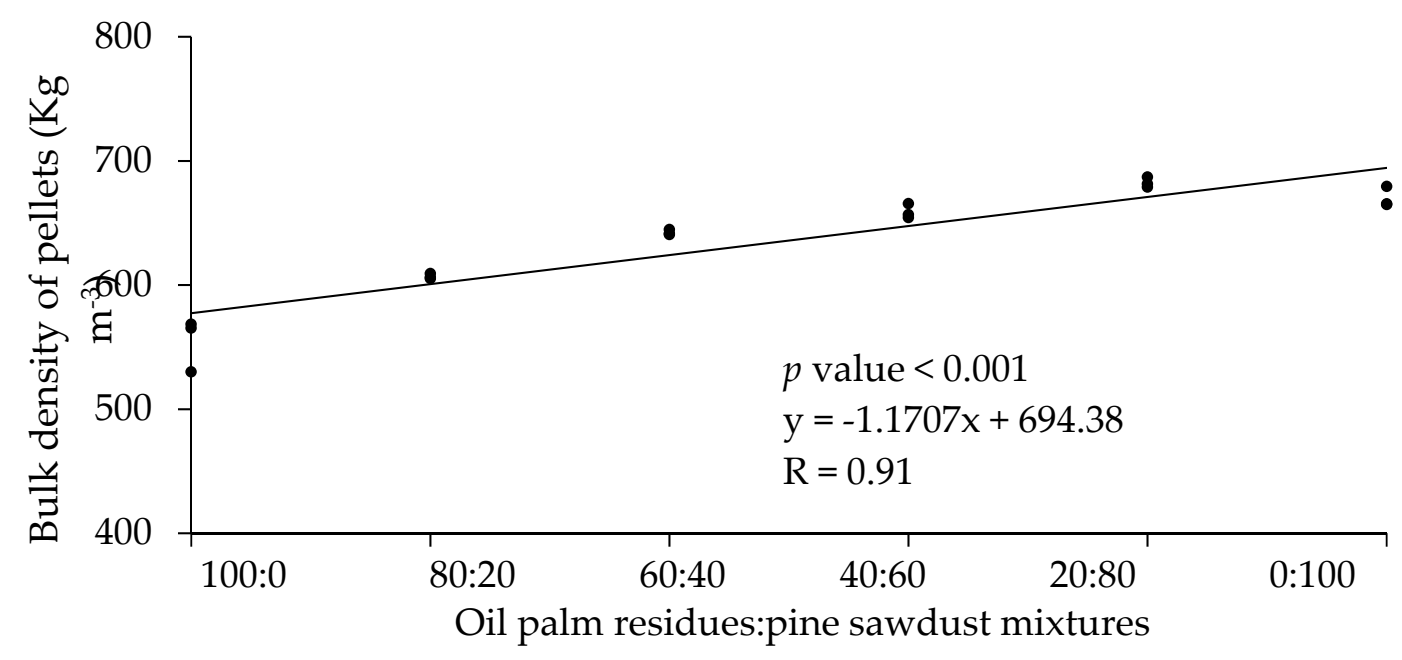

(a)

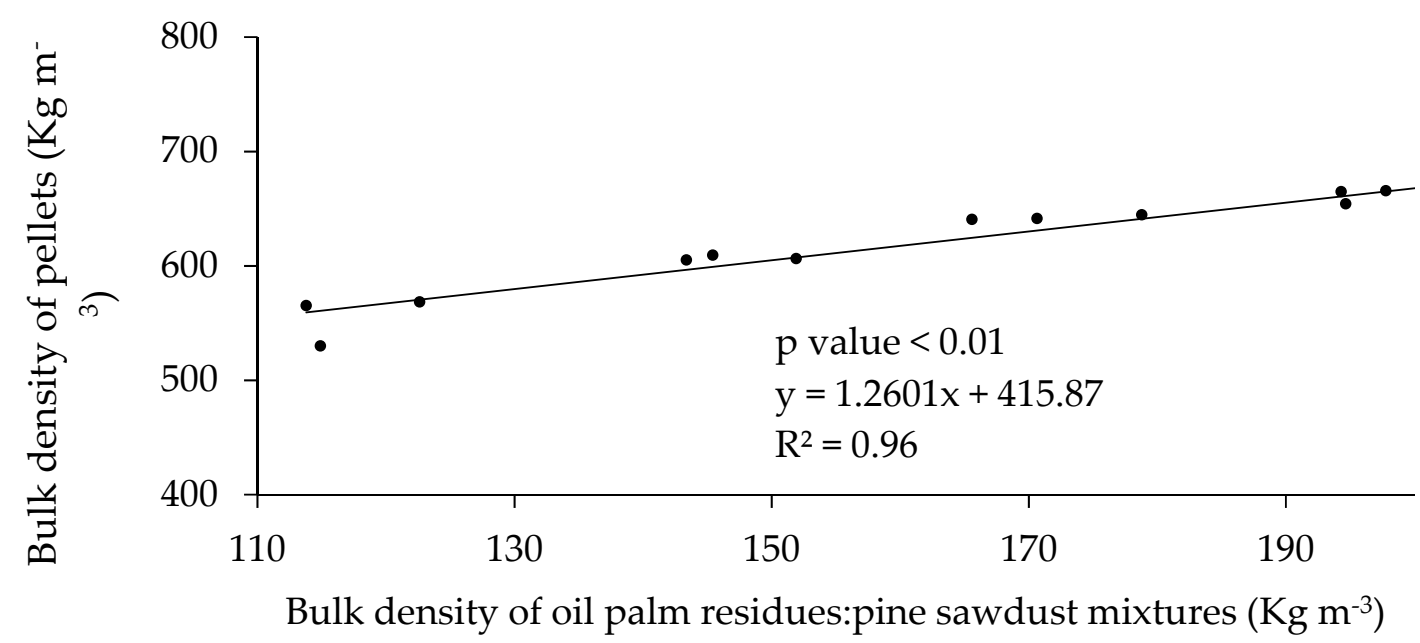

(b)

Figure 2. Relationship of bulk density of agro-pellets with: (a) mixing ratios of oil palm residues:pine sawdust; (b) bulk density of oil palm residues:pine sawdust mixtures.

\subsection{Relationship of Agro-Pellets Energy with Mixtures and Proximate Elements}

Gross calorific values showed a high degree of correlation coefficients $(r)$ with oil palm residues:pine sawdust mixtures $(\mathrm{R}=0.94, p<0.0001)$; fixed carbon $(\mathrm{R}=0.81, p<0.05)$; and with volatile matter of oil palm residues:pine sawdust mixtures $(R=0.81, p<0.05)$ (Figure $3 b, c)$. 


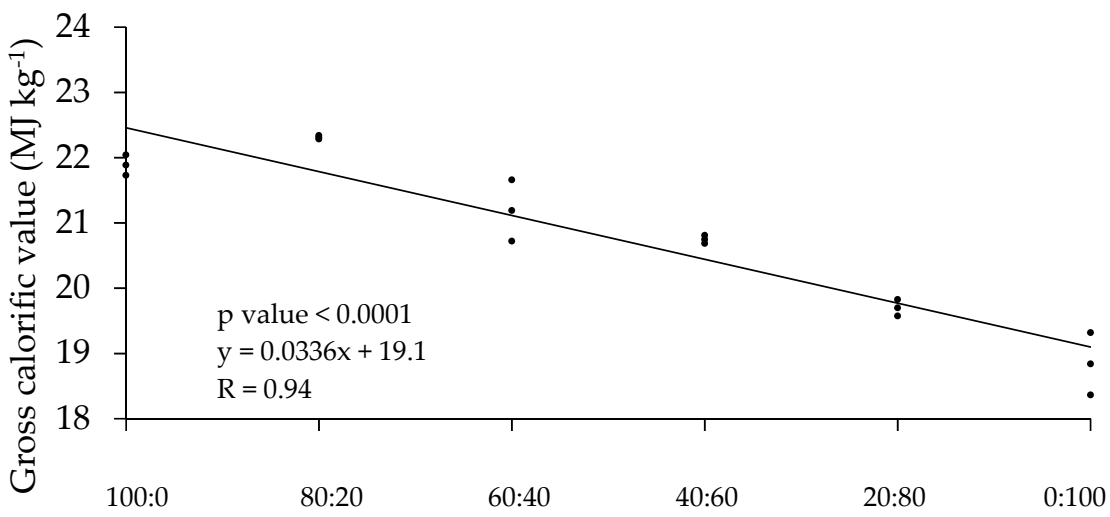

Oil palm residues:pine sawdust mixtures

(a)

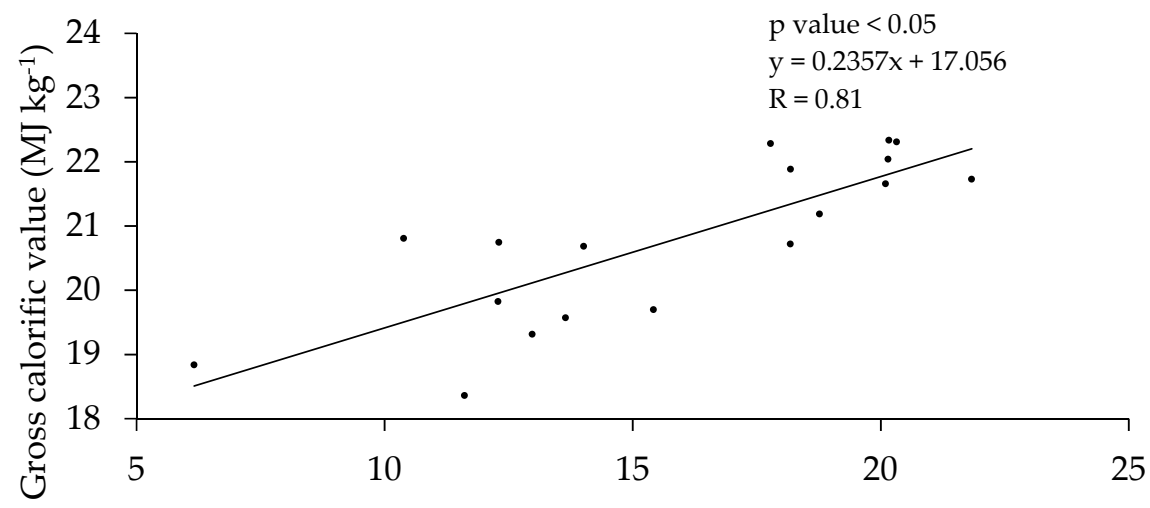

Fixed carbon (\%) of oil palm residues:pine sawdust mixtures

(b)

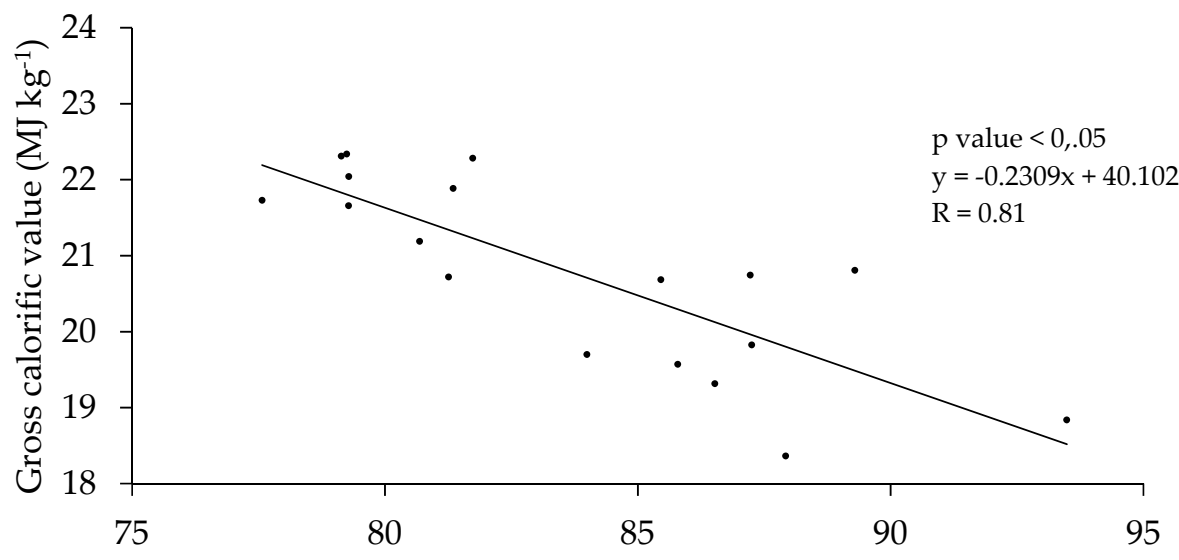

Volatile matter (\%) of oil palm residues:pine sawdust mixtures

(c)

Figure 3. Relationship of gross calorific values of agro-pellets with (a) mixing ratios of oil palm residues:pine sawdust; (b) fixed carbon of oil palm residues:pine sawdust mixtures, and (c) volatile matter of oil palm residues:pine sawdust mixtures. 


\section{Discussion}

\subsection{Agro-Pellets Characterization}

The effect of mixing pine sawdust with palm residues can explain the non-linear behavior of moisture content, which also affects the other variables. In the 100-0 proportion, there are only volatiles $(84 \%)$ of the oil palm residues, while in $80-20$, the volatiles increase (up to around 88 ) due to the volatiles contained in the pine sawdust. However, they drop to $87 \%$ in the $60-40$ mixture due to the fact that the increase of the palm fiber "encapsulates" the volatiles, which is why they are released in a low proportion when the analysis is made. The same happens in the 20-80 mixture. However, in the 0-100 mixture, where there is more humidity, at the time of determining the immediate ones, it allows increasing the leaching of the volatiles at $100{ }^{\circ} \mathrm{C}$; therefore, the percentage $(\%)$ of volatiles increases.

For the agro-pellets from all of the mixtures, moisture content values varied in the range $5.58-6.77 \%$, meeting < 10\% established by the standard ISO 17225-2 [30]. Values were lower than 9.0 to $9.2 \%$, presented by Tenorio et al. [31]. Higher moisture content values (than 10\%) affects the burning characteristics of biomass material and reduces agro-pellet strength and durability. Volatile material of agro-pellets presented the range $79.40-89.31 \%$, similar to $79.58-85.11 \%$ reported by Onochie et al. [32]. The highest values were found in the mixtures 40:60, 20:80, and 0:100 when pine sawdust percent was high; this can be attributed to higher percent of lignin and volatile material pine sawdust in the mixtures (Table 1; Table 2), high volatile material on fuel pellets ease the ignition during combustion. Ash was significantly similar $(p>0.05)$ on all mixtures of agro-pellets and ranged from 0.44 to $0.58 \%$ (Table 2), meeting class A1, according to the European Committee for Standardization (CEN in spanish), CEN/TS EN 14961-2 [33]. However, combination 40:60 was in A0.5, while all other combinations were in class A0.7. Ash content values higher than $0.7 \%$ increase particle dispersion and allow particle adherence inside of boilers [34,35]. Fixed carbon showed the ranged $10.25-20.05 \%$, with high values in mixtures of high oil palm residue proportion (100:0, 80:20, and 60:40). Values of these mixtures were higher than $16.87 \%$, as reported by Forero Nunez et al. [12]. The distribution follows the same relationship found on oil palm residues:pine sawdust mixtures (Table 1). Fixed carbon, together with volatile material, increase the gross calorific value [36].

Bulk density values varied from 540 to $680 \mathrm{Kg} \mathrm{m}^{-3}$, except for the mixture 100:0, all mixtures achieve quality parameters ( $>550 \mathrm{~kg} \mathrm{~m}^{-3}$ ) of ISO 17225-2 [30] (Table 2). As was seen, increasing the proportion of pine sawdust in the mixture (100:20-0:100\%) increased bulk density values from 610 to $670 \mathrm{~kg} \mathrm{~m}^{-3}$. Bulk density is considered as a good quality indicator for pellets [37]. Particle density varied in the range $1090-1340 \mathrm{Kg} \mathrm{m}^{-3}$, and were similar to those reported of agro-pellets produced from 12 types of agricultural and forest residues (1100-1290 $\mathrm{kg} \mathrm{m}^{-3}$ ) [31]. Density values reduced when the pine sawdust proportion increased, similar to that reported by Hosseinizand et al. [38]. This is consistent with low density that typically characterizes lignocellulosic and fibrous materials, such as sawdust, as indicated by Ferero-Nuñez et al. [18]. Such materials present void spaces throughout their structures-full of air that increases the volume of the solid. After milling, the powder becomes finer, releasing the air inside and raising the density.

The highest compression ratios (4.75-4.13) of agro-pellets were obtained on mixtures of 100:0 and 80:20; the lowest (3.28-3.29) on mixtures of 40:60, 20:80, and 100:0. Compression ratio is a way to determine the effectiveness of densification; high compression values reduce cost during transportation, and handle management of biomass as a source of energy. In this concern, compression ratios found in this research were similar to 3.74-4.86 of Artemisia dubia Wall., presented by Zvicevičius et al. [39] when applying different pressure. Impact resistance indexes of mixtures varied in the range 108-157 and differed significantly $(p<0.05)$ among mixtures (Table 2$)$. Higher values were obtained on mixtures with high palm oil residues (100:0 and 80:20); however, values of all mixtures were considerably higher than 50; target considered by Richards [28]. Impact resistance is another important physical property for pellets, since high values reduce the dust production during handle and transport; this 
may produce irritation of the lungs, nasal, and respiratory system, with inhalation of an excessive amount of dust particles.

Gross calorific values varied in the range 18.84-22.31 (MJ/Kg) and were similar to 17.78-20.51 MJ $\mathrm{kg}^{-1}$ reported for pellets from oil palm frond [20]. The highest value was obtained in the mixture 80:20 and the lowest in the mixture 0:100, in accordance with $18.9 \mathrm{MJ} \mathrm{kg}-1$, established for pine sawdust [40]. Increasing the proportion of oil palm residues increased the gross calorific value (GCV), which could be related to the highest amount of volatile material and fixed carbon, contrary to Obernberger and Thek [41], who stated that volatile matter provides low energy, because they vaporize before combustion reactions take place. For Forero-Nuñez et al. [12], volatile matter content and fixed carbon are parameters that affect the combustion process directly. In their study, these authors obtained that pine sawdust has more volatile compounds than palm oil shells, but less fixed carbon content. So that pine sawdust will release more volatile material at the first stage of the combustion process, the palm oil residues will add energy for char combustion, since materials with high fixed carbon content have more elemental carbon, and then, more energy power. In this way, the oil palm residues/pine sawdust mixture is necessary to establish the potential of these materials as energy sources for further processes, such as combustion or gasification and, above all, their palletization will increase their energy density.

\subsection{Relationships of Agro-Pellets Characteristics and Raw Material Properties}

The relationship of pellet characteristics and some chemical and physical properties of oil palm residues:pine sawdust mixtures was contrasting. Bulk density of agro-pellets was related with the chemical components cellulose, hemicellulose, lignin, and extracts on oil palm residues:pine sawdust biomass mixtures, as was seen (Figure 1a,b) when increasing the amount of cellulose and lignin, increasing pellets bulk density, both are considered as natural binderies and responsible for bonding [42]. On the one hand, cellulose is the main (and the strongest) mass compound on lignocellulosic matrix; this increases friction, providing density of pellets during pelletizing. On the other hand, lignin provides hardness after pelletizing, where biomass is heated at high temperature and pressure, its low melting point becomes soft and melts with the particles; after that, pellets cool $[13,43]$. In contrast to the previous, hemicellulose considered as the weakest parties on polymer structure in wood matrix reduces the bulk density; while extracts, as a mixture of different compounds, migrate during pelletizing to the pellet surface and reduce friction, producing weak pellets [44].

The increment of bulk density on agro-pellets was also seen when the proportion of pine sawdust increased in the mixture, the same was observed when increasing the bulk density of raw material (Figure 1a,b). This is consistent with the study carried out by Li and Liu [45], attributing it to the bonding strength between small and long particles that stick together strongly.

Gross calorific values of pellets varied in the range $18.84-22.31 \mathrm{MJ} \mathrm{Kg}^{-1}$; values showed a reduction when increasing the pine sawdust proportion in the mixture (Figure 3a). The same trend (17.02-22.72 $\mathrm{MJ} / \mathrm{kg}$ ) was presented by Sirrajudin et al. [46] after add glycerin on percentage of 15,30 , and $45 \%$ to oil palm fronds, they ascribed this to major biochemical components, such as cellulose, hemi-cellulose, lignin, extractives, and other ash forming minerals [47].

\section{Conclusions}

Agro-pellets elaborated from mixtures of oil palm residues and pine sawdust show quality parameters that meet international standards, completely made from oil palm residues. The addition from 20 to $40 \%$ of pine sawdust to oil palm residues increases gross calorific value, impact resistance index, and compression ratio values. However, they present lowest bulk and particle densities values. Bulk density of oil palm pellets was positively correlated with pine sawdust content; the same relationship was observed with the amount of cellulose and lignin on mixes, but negative with hemicellulose and extracts. Compression ratio was reduced while adding pine sawdust; the most suitable combinations were found at 80:20 and 60:40. 
Author Contributions: Conceptualization, A.C.-P. and M.N.-H.; methodology, A.C.-P., M.N.-H., M.P.-G., M.Á.P.-G., and J.G.R.-Q.; software, G.P.-C., J.C.C.-T., and M.N.-H.; validation, G.P.-C., J.C.C.-T., and M.N.-H.; formal analysis, A.C.-P., M.N.-H., and M.P.-G.; investigation, A.C.-P., M.N.-H., M.P.-G., and G.P.-C.; resources, A.C.-P. and J.G.R.-Q.; data curation, J.C.C.-T.; writing—original draft preparation, A.C.-P.; writing—review and editing, M.N.-H., M.P.-G., M.Á.P.-G., and G.P.-C.; visualization, A.C.-P., J.G.R.-Q and M.N.-H.; supervision, A.C.-P.; project administration, A.C.-P.; funding acquisition, A.C.-P. All authors have read and agreed to the published version of the manuscript.

Funding: This research was funded by the Energy Sustainability Fund through the project SENER CONACYT 2014 (No 246911): Cluster of Solid Biofuels for Thermal and Electric Generation. The funders had no role in the study design, data collection and analysis, decision to publish, or preparation of the manuscript.

Acknowledgments: We thank SENER-CONACYT for funding "Fondo de Sustentabilidad Energética", grant number SENER-CONACYT 2014246911 "Clúster de Biocombustibles Sólidos para la generación térmica y eléctrica" and CONACYT project 166444.

Conflicts of Interest: The authors declare no conflict of interest.

\section{References}

1. Malico, I.; Carrajola, J.; Gomes, C.P.; Lima, J. Biomass residues for energy production and habitat preservation. Case study in a montado area in Southwestern Europe. J. Clean. Prod. 2016, 112, 3676-3683. [CrossRef]

2. Rios, M.; Kaltschmitt, M. Bioenergy potential in Mexico-Status and perspectives on a high spatial distribution. Biomass Convers. Biorefin. 2013, 3, 239-254. [CrossRef]

3. Mani, S.; Sokhansanj, S.; Bi, X.; Turhollow, A. Economics of producing fuel pellets from biomass. Appl. Eng. Agric. 2006, 22, 421-426. [CrossRef]

4. Zheng, A.; Zhao, Z.; Chang, S.; Huang, Z.; Wang, X.; He, F.; Li, H. Effect of torrefaction on structure and fast pyrolysis behavior of corncobs. Bioresour. Technol. 2013, 128, 370-377. [CrossRef]

5. Stelte, W.; Holm, J.K.; Sanadi, A.R.; Barsberg, S.; Ahrenfeldt, J.; Henriksen, U.B. A study of bonding and failure mechanisms in fuel pellets from different biomass resources. Biomass Bioenergy 2011, 35, 910-918. [CrossRef]

6. Nielsen, N.P.K.; Gardner, D.J.; Poulsen, T.; Felby, C. Importance of temperature, moisture content, and species for the conversion process of wood residues into fuel pellets. Wood Fiber Sci. 2009, 41, 414-425.

7. Kiss, I.; Alexa, V.; Sárosi, J. About the wood sawdust-one of the most important renewable energy sources. Ann. Fac. Eng. Hunedoara 2016, 14, 215.

8. Owoyemi, J.M.; Zakariya, H.O.; Elegbede, I. Sustainable wood waste management in Nigeria. Environ. Socio Econ. Stud. 2016, 4, 1-9. [CrossRef]

9. Cocchi, M.; Nikolaisen, L.; Junginger, M.; Goh, C.S.; Heinimö, J.; Bradley, D.; Thrän, D. Global wood pellet industry market and trade study. In IEA Bioenergy Task; IEA Bioenergy: Dutch, The Netherlands, 2011; Volume 40, p. 190.

10. Šafran, B.; Jug, M.; Radmanović, K.; Đukić, I.; Kramar, D.; Beljo-Lučić, R.; Risović, S. Analysis of the Raw Material Properties in the Agro-wood Pellets Production. In Proceedings of the 28th International Conference on Wood Science and Technology, Zagreb, Croatia, 7-8 December 2017.

11. Pastre, O. Analysis of the Technical Obstacles Related to the Production and Utilisation of Fuel Pellets Made from Agricultural Residues. Available online: http://www.Pelletcentre.Info/Resources/1093.Pdf (accessed on 9 November 2019).

12. Forero-Nuñez, C.A.; Jochum, J.; Sierra-Vargas, F.E. Characterization and feasibility of biomass fuel pellets made of Colombian timber, coconut and oil palm residues regarding European standards. Environ. Biotechnol. 2012, 8, 67-76.

13. Kaliyan, N.; Morey, R.V. Factors affecting strength and durability of densified biomass products. Biomass Bioenergy 2009, 33, 337-359. [CrossRef]

14. Serrano, C.; Monedero, E.; Lapuerta, M.; Portero, H.; Villalba, M.E.M. Effect of moisture content, particle size and pine addition on quality parameters of barley straw pellets. Fuel Process. Technol. 2011, 92, 699-706. [CrossRef]

15. Kuokkanen, M.J.; Vilppo, T.; Kuokkanen, T.; Stoor, T.; Niinimäki, J. Additives in wood pellet production-A pilot-scale study of binding agent usage. Bioresources 2011, 6, 4331-4355. [CrossRef]

16. Atuesta-Boada, L.E.; Sierra-Vargas, F.E. Caracterización físico-química de pellets producidos a partir de mezclas 50/50 carbón bituminoso/madera residual. Inf. Técnico 2015, 79, 18-25. [CrossRef] 
17. Vijay, V.; Pimm, S.L.; Jenkins, C.N.; Smith, S.J. The Impacts of Oil Palm on Recent Deforestation and Biodiversity Loss. PLoS ONE 2016, 11, e0159668. [CrossRef] [PubMed]

18. Forero-Núñez, C.A.; Jochum, J.; Sierra-Vargas, F.E. Effect of particle size and addition of cocoa pod husk on the properties of sawdust and coal pellets. Ing. Investig. 2015, 35, 17-23. [CrossRef]

19. Munawar, S.S.; Subiyanto, B. Characterization of Biomass Pellet Made from Solid Waste Oil Palm Industry. Procedia Environ. Sci. 2014, 20, 336-341. [CrossRef]

20. Trangkaprasith, K.; Chavalparit, O. Heating value enhancement of fuel pellets from frond of oil palm. In International Conference on Biology, Environment and Chemistry; IACSIT Press: Singapore, 2011.

21. Goering, H.K.; Van Soest, P.J. Forage Fiber Analysis. Apparatus, Reagents, Procedures and Some Applications; Agricultural Research Service, US Department of Agriculture: Washington, DC, USA, 1970; Volume 379, p. 20.

22. UNE-EN-14774. Biocombustibles Sólidos. Determinación del Contenido de Humedad. Método de Secado en Estufa; Parte H; Asociación Española de Normalización y Certificación: Madrid, Spain, 2010.

23. UNE-EN 15148. Biocombustibles Sólidos. Determinación del Contenido en Materias Volátiles; Asociación Española de Normalización y Certificación (AENOR): Madrid, Spain, 2010.

24. UNE-EN-14775. Biocombustibles Sólidos. Método Para la Determinación del Contenido en Cenizas; Asociación Española de Normalización y Certificación (AENOR): Madrid, Spain, 2010.

25. UNE-EN 14918. Determinación del Poder Calorífico; UNE-EN 14918:2011; Asociación Española de Normalización y Certificación (AENOR): Madrid, Spain, 2011.

26. UNE-ENISO 17828. Biocombustibles Sólidos Determinación de la Densidad a Granel; Asociación Española de Normalización y Certificación (AENOR): Madrid, Spain, 2016.

27. Acda, M.N.; Devera, E.E. Physico-chemical properties of wood pellets from forest residues. J. Trop. For. Sci. 2014, 26, 589-595.

28. Richards, S. Physical testing of fuel briquettes. Fuel Process. Technol. 1990, 25, 89-100. [CrossRef]

29. Steel, R.G.D.; Torrie, J.H. Principles and Procedures of Statistics. Biometrika 1961, 48, 234. [CrossRef]

30. ISO 17225. Solid Biofuels-Fuel Specifications and Classes-Part 1: General Requirements; International Organization for Standardization: Geneva, Switzerland, 2014.

31. Tenorio, C.; Moya, R.; Tomazello-Filho, M.; Valaert, J. Quality of Pellets Made from Agricultural and Forestry Crops in Costa Rican Tropical Climates. Bioresources 2014, 10, 482-498. [CrossRef]

32. Onochie, U.P.; Obanor, A.I.; Aliu, S.A.; Igbodaro, O.O. Proximate and ultimate analysis of fuel pellets from oil palm residues. Niger. J. Technol. 2017, 36, 987-990.

33. CEN/TS EN 14961-2. Solid Biofuels_Fuel Specification and Classes-Wood Pellets for Non-Industrial Use; Asociación Española de Normalización y Certificación (AENOR): Madrid, Spain, 2012.

34. Correa-Méndez, F.; Carrillo-Parra, A.; Rutiaga-Quiñones, J.G.; Márquez-Montesino, F.; González-Rodríguez, H.; Jurado-Ybarra, E.; Garza-Ocañas, F. Moisture and Inorganic Substance Content in Pine Timber Products for Use in Pellets and Briquettes. Rev. Chapingo Ser. Cienc. For. Ambient. 2014, 20, 77-88. [CrossRef]

35. Thek, G.; Obernberger, I. The Pellet Handbook: The Production and Thermal Utilization of Biomass Pellets; Routledge: London, UK, 2012.

36. Tenorio, C. Characterisation of pellets made from oil palm residues in costa rica. J. Oil Palm Res. 2016, 28, 198-210. [CrossRef]

37. Mani, S.; Tabil, L.G.; Sokhansanj, S. Effects of compressive force, particle size and moisture content on mechanical properties of biomass pellets from grasses. Biomass Bioenergy 2006, 30, 648-654. [CrossRef]

38. Hosseinizand, H.; Sokhansanj, S.; Lim, C.J. Co-pelletization of microalgae Chlorella vulgaris and pine sawdust to produce solid fuels. Fuel Process. Technol. 2018, 177, 129-139. [CrossRef]

39. Zvicevičius, E.; Raila, A.; Čiplienè, A.; Černiauskienè, Ž.; Kadziuliene, Z.; Tilvikienè, V. Effects of moisture and pressure on densification process of raw material from Artemisia dubia Wall. Renew. Energy 2018, 119, 185-192. [CrossRef]

40. Riaza, J.; Khatami, R.; Levendis, Y.A.; Álvarez, L.; Gil, M.V.; Pevida, C.; Rubiera, F.; Pis, J.J.; Pevida, C. Combustion of single biomass particles in air and in oxy-fuel conditions. Biomass Bioenergy 2014, 64, 162-174. [CrossRef]

41. Obernberger, I.; Thek, G. Physical characterisation and chemical composition of densified biomass fuels with regard to their combustion behaviour. Biomass Bioenergy 2004, 27, 653-669. [CrossRef] 
42. Kaliyan, N.; Morey, R.V. Natural binders and solid bridge type binding mechanisms in briquettes and pellets made from corn stover and switchgrass. Bioresour. Technol. 2010, 101, 1082-1090. [CrossRef]

43. Van Dam, J.E.; VandenOever, M.; Teunissen, W.; Keijsers, E.; Peralta, A. Process for production of high density/high performance binderless boards from whole coconut huskPart 1: Lignin as intrinsic thermosetting binder resin. Ind. Crop. Prod. 2004, 19, 207-216. [CrossRef]

44. Stelte, W.; Sanadi, A.R.; Shang, L.; Holm, J.K.; Ahrenfeldt, J.; Henriksen, U.B. Recent developments in biomass pelletization-A review. Bioresources 2012, 7, 4451-4490.

45. Li, Y.; Liu, H. High-pressure densification of wood residues to form an upgraded fuel. Biomass Bioenergy 2000, 19, 177-186. [CrossRef]

46. Sirrajudin, M.S.; Rasat, M.S.M.; Wahab, R.; Amini, M.H.M.; Mohamed, M.; Ahmad, M.I.; Moktar, J.; Ibrahim, M.A. Enhancing the energy properties of fuel pellets from oil palm fronds of agricultural residues by mixing with glycerin. ARPN J. Eng. Appl. Sci. 2016, 11, 6122-6127.

47. Kataki, R.; Konwer, D. Fuelwood characteristics of indigenous tree species of north-east India. Biomass Bioenergy 2002, 22, 433-437. [CrossRef]

(C) 2020 by the authors. Licensee MDPI, Basel, Switzerland. This article is an open access article distributed under the terms and conditions of the Creative Commons Attribution (CC BY) license (http://creativecommons.org/licenses/by/4.0/). 